\title{
Magnetic Susceptibilities in the Cretaceous-Paleogene Section in Uzgruň, Czech Republic
}

\author{
Tiiu Elbra1, Petr Schnabl1 ${ }^{*}$, Šimon Kdýr ${ }^{1}$, Miroslav Bubík ${ }^{2}$ \\ ${ }^{1}$ Institute of Geology of the Czech Academy of Sciences, Prague, Czech Republic \\ ${ }^{2}$ Czech Geological Survey, Brno, Czech Republic \\ Email: *schnabl@gli.cas.cz
}

How to cite this paper: Elbra, T., Schnabl, P., Kdýr, Š. and Bubík, M. (2019) Magnetic Susceptibilities in the Cretaceous-Paleogene Section in Uzgruň, Czech Republic. Open Journal of Geology, 9, 665-667. https://doi.org/10.4236/ojg.2019.910069

Received: August 16, 2019

Accepted: September 21, 2019

Published: September 24, 2019

Copyright () 2019 by author(s) and Scientific Research Publishing Inc. This work is licensed under the Creative Commons Attribution International License (CC BY 4.0).

http://creativecommons.org/licenses/by/4.0/

\section{c) (i) Open Access}

\begin{abstract}
A new multidisciplinary study is being carried out in several localities from Outer Carpathians of Central Europe. Outer Carpathians allow studying the Cretaceous-Paleogene (K-Pg) interval of the oceanic facies, including lower bathyal-abyssal sub-CCD turbidites. Preliminary results of field-measured magnetic susceptibilities from Uzgruň K-Pg section in the Czech Republic are presented.
\end{abstract}

\section{Keywords}

Cretaceous-Paleogene, Outer Carpathians, Magnetic Susceptibilities

\section{Introduction}

The Cretaceous-Paleogene (K-Pg) boundary marks the limit between the Cretaceous and Paleogene periods and coincides with one of the five large mass extinctions in Earth's history. A new research project "Cretaceous-Paleogene boundary in the Carpathians-multidisciplinary search for local variations in global cataclysm event" was launched at the beginning of 2019. The project comprises of magnetic, biostratigraphic, sedimentological and geochemical investigations of several Central European Carpathian sections in order to characterize the K-Pg transition sequence in deep-sea sub-CCD facies, to provide paleoenvironmental information and study its impact to magnetic and biotic changes. One of the key locations of this research is Uzgruň, Czech Republic (Figure 1).

\section{Uzgruň Section}

The Uzgruň section is situated near Velké Karlovice village and represents a 

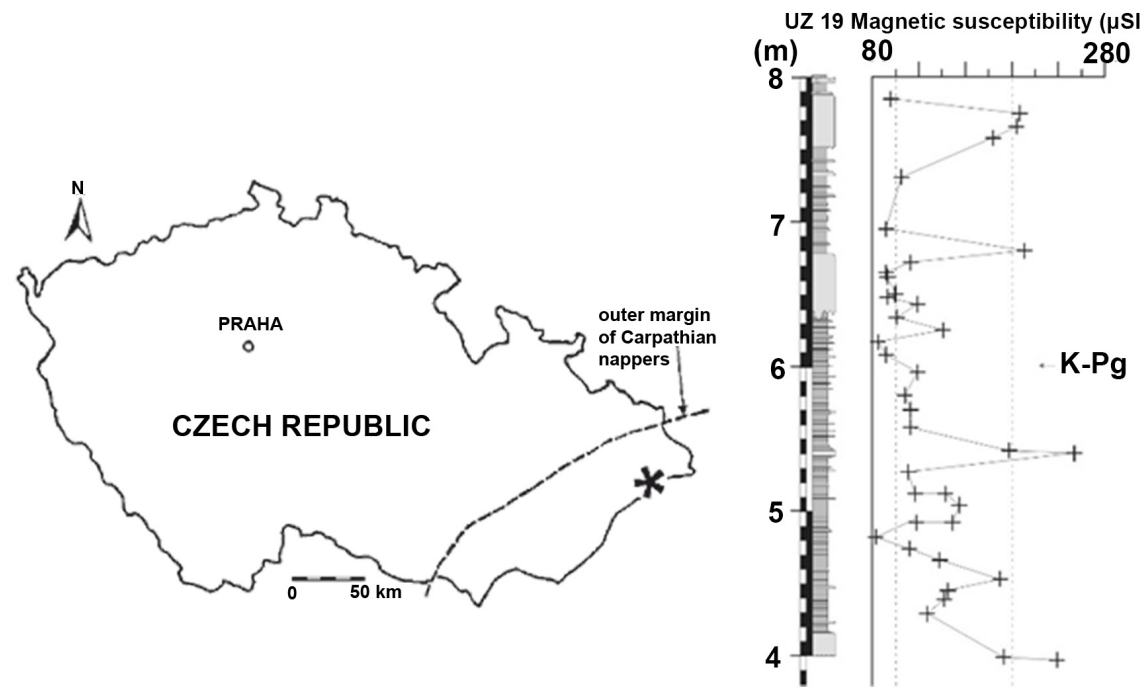

Figure 1. Left: Schematic map of the Uzgruň section location. Right: Magnetic susceptibility of UZ 19 subsection.

continuous composite section. The section belongs to the Solán Formation of the Rača Unit and is predominantly built up by turbiditic sequences of calcareous and non-calcareous claystones with thin siltstone intercalations as well as occasional sandstones and marlstones [1]. The composite section comprises three subsections in different tectonic slices that are correlated using characteristic sequence of marker turbidite layers. Fossil record of Uzgruň includes benthic agglutinated foraminifers, nannofossils, radiolarians and organic-walled dinocysts. A biostratigraphic study was carried out at the end of 1990's-early 2000's and resulting integrated biostratigraphy is summarized by Bubík et al. [2]. The base of the Danian is indicated by the lowest occurrence of dinocyst Carpatella cornuta and supported by typical sequence of dinocysts, radiolarians and benthic foraminifers. More recently, the entire Micula prinsii zone of the topmost Maastrichtian was confirmed in the section.

\section{Sampling and Results}

A new sampling of the Uzgrun locality was carried out during summer 2019 to magnetically characterize the local K-Pg as well as revise and extend the fossil and geochemical record and, thus, gain insights to local variations of paleoenvironment. To assist with sample selection for rock- and paleomagnetic laboratory study, and provide the first outline of magnetic properties, the magnetic susceptibility of the composite section was measured in the field using portable susceptibility meter KT-10.

The preliminary results of field measurements of magnetic susceptibility indicate mostly paramagnetic behavior (Figure 1). Several slightly higher magnetic intervals were identified and, for the most part, seem to correspond to sandstone layers. The field measurements don't appear to display a higher magnetic susceptibility zone at suggested K-Pg boundary; however, more detailed laboratory 
measurements are needed to verify the presence or absence of any distinct magnetic signatures at the K-Pg boundary in Uzgrun.

\section{Acknowledgements}

The study is funded by Czech Science Foundation project no. 19-07516S and is in accordance of research plan no. RVO67985831. This is a contribution to UNESCO/IUGS/IGCP 679 project.

\section{Conflicts of Interest}

The authors declare no conflicts of interest regarding the publication of this paper.

\section{References}

[1] Bubík, M., Bąk, M. and Švábenická, L. (1999) Biostratigraphy of the Maastrichtian to Paleocene Distal Flysch Sediments of the Rača Unit in the Uzgruň Section (Magura Group of Nappes, Czech Republic). Geologica Carpathica, 50, 33-48.

[2] Bubík, M., Adamová, M., Bąk, M., Franců, E., Franců, J., Gedl, P., Mikuláš, R., Švábenická, L. and Uchman, A. (2002) Results of the Investigations at the Cretaceous/Tertiary Boundary in the Magura Flysch near Uzgrun.. Get this from a library! Geologické výzkumy na Moravě a ve Slezsku v roce, Brno, 18-22. (In Czech)

https://doi.org/10.5817/gvms2014-1-2-10 